\title{
Simple Endometrial Hyperplasia
}

National Cancer Institute

\section{Source}

National Cancer Institute. Simple Endometrial Hyperplasia. NCI Thesaurus. Code C35463.

A proliferation of endometrial cells resulting in glandular enlargement and budding without changes in the basic structure of the endometrium. Epithelial atypia may be present or absent. 